\title{
To be or not to be local: a provenance study of archaeological ceramics from Shahr-i Sokhta, eastern Iran
}

\author{
Negar Eftekhari ${ }^{1}$ Parviz Holakooei ${ }^{2}$ Elena Marrocchino ${ }^{1} \cdot$ Carmela Vaccaro $^{1,3}$
}

Received: 23 November 2020 / Accepted: 24 February 2021 / Published online: 27 March 2021

(C) The Author(s) 2021

\begin{abstract}
Findings from the archaeological site of Shahr-i Sokhta in eastern Iran include a wide range of undecorated, monochrome, and polychrome ceramics with gray, red, and buff-colored bodies that date back to a period spanning from 3200 to 1800 B.C.E. Given the large number and variety of ceramics unearthed from Shahr-i Sokhta, the provenance of these wares has remained a subject of controversy. Based on compositional data obtained from quantitative wavelength dispersive X-ray fluorescence (WDXRF) spectroscopy studies and petrographic observations, findings from this study provide information that can be used to determine whether the ceramics from Shahr-i Sokhta were manufactured locally or were imported from elsewhere. We show here that the chemical components of a large group of ceramics with gray, red, and buff-colored bodies are similar to those found in local clay sources and kiln wasters, suggesting local production of these wares. However, one group of red and gray-colored wares demonstrated entirely different chemistry, suggesting a different origin. In support of the quantitative WDXRF data, petrofabric analysis of the first group of buff, gray, and red wares revealed poorly sorted basaltic clasts similar to those found randomly distributed in the matrix of local clays. By contrast, the non-local gray and red wares exhibited fine-grained clay bodies with sorted distribution of fine-grained quartz within the clay matrix.
\end{abstract}

Keywords Shahr-i Sokhta $\cdot$ Bronze Age $\cdot$ Ceramic $\cdot$ Polychrome ware $\cdot$ WDXRF $\cdot$ Petrography

\section{Introduction}

The Bronze Age archaeological site of Shahr-i Sokhta (Burnt City) covers an area of 150 hectares in eastern Iran near the modern border of Pakistan (Fig. 1, left). The main excavated parts of the site have been identified as the "residential area" (including "central quarters," "oriental residential area," "burnt building," and "monumental area"), the "industrial zone," and the "graveyard" (Fig. 1, right). The clay-based archaeological finds from Shahr-i Sokhta include small sculptures with anthropomorphic and zoomorphic figures that were most probably used for ritual purposes and a large amount of

Negar Eftekhari

negar.eftekhari@unife.it

1 Department of Physics and Earth Sciences, University of Ferrara, Block B, Room 107, Via Saragat, 1, 44122 Ferrara, Italy

2 Department of Objects Conservation and Archaeometry, Art University of Isfahan, Isfahan, Iran

3 Institute of Atmospheric Sciences and Climate CNR-ISAC, Bologna, Italy pottery that included bowls, cups, vases, trays, and plates (Sajjadi 2005). The color of ceramic paste used by the inhabitants of Shahr-i Sokhta varied from buff-colored and gray to red (Tosi 1969; Vidale and Bennici 1995; Mugavero 2008; Sajjadi 2009; Biscione 2010; Festuccia 2011). The undecorated buff ware is believed to have been used for domestic and daily tasks, given the large number of these items that have been unearthed from the site. While many of buff ceramics are undecorated, the decorated buff ware bears simple geometric patterns with rare animal figures and vegetal motifs (Tosi 1983).

Examples of painted pottery from Shahr-i Sokhta include monochrome ware (with either black or brown-painted motifs), bichrome ware (with two red and black-painted decorations), and polychrome ware (painted with white, red, black, yellow, and green colors) executed with different colors of paste (Eftekhari et al., 2018). Polychrome ceramics with buff-colored bodies were found at the cemetery site of Shahr-i Sokhta; these are considered to be imported products (Sajjadi 2004; Piperno 2006; Mugavero 2008; Cortesi et al. 2008; Sajjadi 2009; Festuccia 2011). The similarities shared by these polychrome ceramics with those found in 

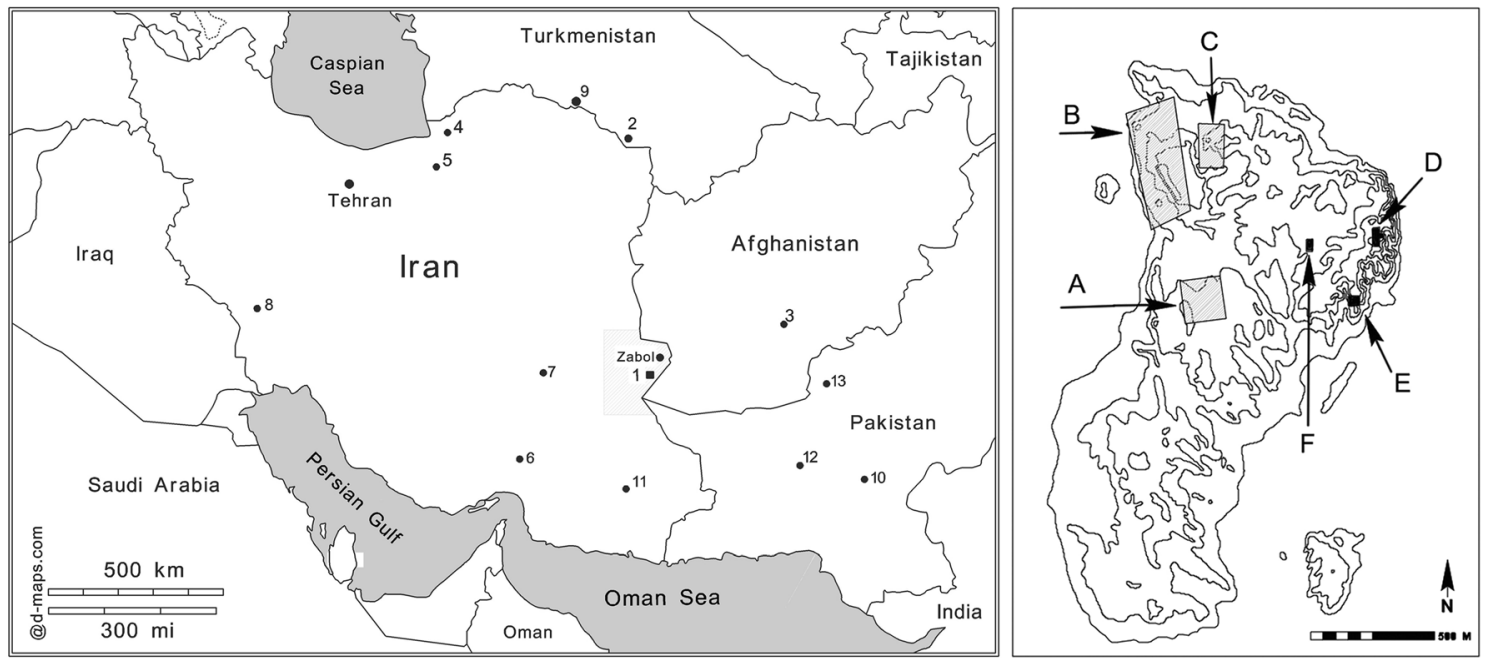

Fig. 1 (Left) Location of Shahr-i Sokhta together with several other important archaeological sites. 1, Shahr-i Sokhta; 2, Altyn Tape; 3, Mundigak; 4, Tureng Tape; 5, Tape Hissar; 6, Tape Yahya; 7, Shahdad; 8, Susa; 9, Namazga; 10, Muhenju daro; 11, Bampur; 12. Nal; and 13,
Quetta. (Right) The main excavation sites at Shahr-i Sokhta. A, graveyard; B, industrial zone; $\mathrm{C}$, monumental area; $\mathrm{D}$, oriental residential areas; E, burnt building; and F, central residential area. Reproduced from the topographic map of the Research Base Centre of Shahr-i Sokhta neighboring archaeological sites (e.g., $\mathrm{Nal}$ and Mundigag in Pakistan; Festuccia 2011) stand in support of this hypothesis (Sajjadi 2004). Furthermore, the pigments used for paintings on the polychrome ware were different from those used to decorate local buff-paste ceramics (Eftekhari et al. 2018).

Four periods of settlement can be distinguished from one another at the Shahr-i Sokhta site based on eleven structural layers spanning from 3200 to 1800 B.C.E. (Tosi 1976; Biscione et al. 1977; Sajjadi 2004). Pottery from Period I (ca. 3200-2800 B.C.E., layers 10, 9, and 8) typically exhibits light paste colors for the body and rich decorations very similar to those found on ceramics from Mundigag III and Baluchistan (Quetta ware; Biscione 1974; Festuccia 2011). These decorations were found until the beginning of Period II (ca. 2800-2500 B.C.E., layers 7, 6, and 5) which represented a time of significant development in both the size of the city and ceramic technology. Finer raw materials and advanced firing techniques used during this period resulted in ceramics with denser body-paste and pottery that was similar to those found in Bampur III-IV (Vidale and Bennici 1995; Festuccia 2011). Most of the ceramics that were produced and/or imported during this period were buff and gray wares with brown and black decorations (Biscione 1979). Pottery production during Period III (ca. 2500-2200 B.C.E., layers 4 and 3) used forms and depicted motifs that differed significantly from those featured by ceramics of the former periods (Vidale and Bennici 1995). At the beginning of Period III, simple decorative motifs originally found on ceramics became more complex (Biscione 1979) and gray-paste pottery with black decoration (similar to those generated during Bampur IV and Tappe Yahya IV) became more commonplace (Festuccia 2011). Small undecorated bowls with thin bodies also appeared at the end of this period (Biscione 2010). During Period IV (2200 to 1800 B.C.E., layers 2, 1, and 0), the typology of ceramics used at Shahr-i Sokhta underwent significant change (Vidale and Bennici 1995) and included undecorated porous pottery (Vidale 2010) with cream to red paste similar to ceramics manufactured during Namazgah VI and V (Salvatori and Tosi 2001).

In addition to advances in technology, the large collection of ceramics found at Shahr-i Sokhta suggests that there were large-scale trade and cultural exchanges between this city and other important civilizations in this region (Biscione 1974; Salvatori 2006; Mugavero 2008). As the ceramics found at Shahr-i Sokhta share significant similarities with those from other contemporary archaeological sites in southwestern Asia, many scholars have argued in favor of the theory that these items were imported to this site to aid local production (Salvatori 2006). For example, the provenance of the polychrome ceramics, which have been excavated in greater abundance from the regions identified as "graveyards" and were most likely used for ritual and religious purposes, has remained a matter for speculation. The fact that nearly identical styles of pottery, including ceramics with similar motifs and colors, were found at the Nal archaeological site at Baluchistan, Pakistan, prompted scholars to conclude that the polychrome ceramics from Shahr-i Sokhta were imported objects (Sajjadi 2004; Piperno 2006; Mugavero 2008; Cortesi, et al. 2008; Sajjadi 2009; Festuccia 2011). By contrast, Mugavero (2008) suggested that methods for pottery production used in Shahr-i Sokhta were also in practice at Tepe Dash (3 km south of Shahr-i Sokhta) and Tepe Rud-e Biyaban (30 km south of Shahr-i Sokhta) based on an analysis of polychrome pottery shards found at these sites. 
Despite the importance of ceramic production and trade at Shahr-i Sokhta in the ancient history of southwestern Asia, there are only a few scientific studies that focus specifically on a limited number of pottery shards unearthed at this site. Results from several recent studies suggest that ceramics and pottery found at Shahr-i Sokhta were produced locally (Sarhaddi-Dadian et al. 2015; Pourzarghan et al. 2017; Javanshah 2018), although the possibility of ceramic imports into the city remain under consideration (Moradi et al. 2013). As such, there is no firm evidence standing in support of either hypothesis. As such, this study aims to shed light on the origin and provenance of different types of ceramic objects retrieved from Shahr-i Sokhta using data from quantitative wavelength dispersive X-ray fluorescence (WDXRF) spectroscopy and thin section petrography on a collection of pottery shards available from this region.

\section{Geological setting}

Shahr-i Sokhta is located in the Sistan Basin, a site that is geologically well-known for its various types of volcanic tuffs and basalts. The Late Cenozoic alkali basalt crop out along the Neh faults in the Lut block in the west and the Helmand block in the east are separated by the Sistan suture zone (Saadat and Stern 2011; Pang et al. 2012). As shown in the geological map of the Shahr-i Sokhta area (Fig. 2), the western side of Shahr-i Sokhta is situated on fine alluvial and lake sediments of Hamun lake at a site that is not far from the basalts embedded in conglomerate and the sandstones, tuffaceous clastics, and mafic (basic) rocks (Aghanabati et al. 1991). A similar lithographic texture has been identified along the eastern side of Shahr-i Sokhta where mafic and basaltic alluvial sediments are transported via the Helmand river in Afghanistan to Hamum lake (Doebrich et al. 2006). The low elevation of Shahr-i Sokhta near Hamun lake facilitates the deposition of alluvium that originated from the western and eastern mafic structures.

\section{Material and methods}

\section{Samples}

One hundred nine pottery shards from Shahr-i Sokhta, representing the range of stylistic diversity of ceramics from all periods of settlement, were collected and sampled for analysis. The samples were selected based on body-paste color, decoration, appearance (density and thickness), and availability. The potshards under study were classified into three categories based on body color and included 51 samples with buff bodies (i.e., buff ware), 32 samples featuring gray paste (i.e., gray ware), and 26 samples with red bodies (i.e., red ware). Some of these shards were undecorated (68 samples), some were decorated with one color only (i.e., monochrome ware, 35 samples), and a few shards were decorated with multiple colors (i.e., polychrome ware, 6 samples). Among the shards with buff-colored bodies, 21 were decorated with one color and 6 had polychrome decorations. The gray ware included 8 decorated and 24 undecorated

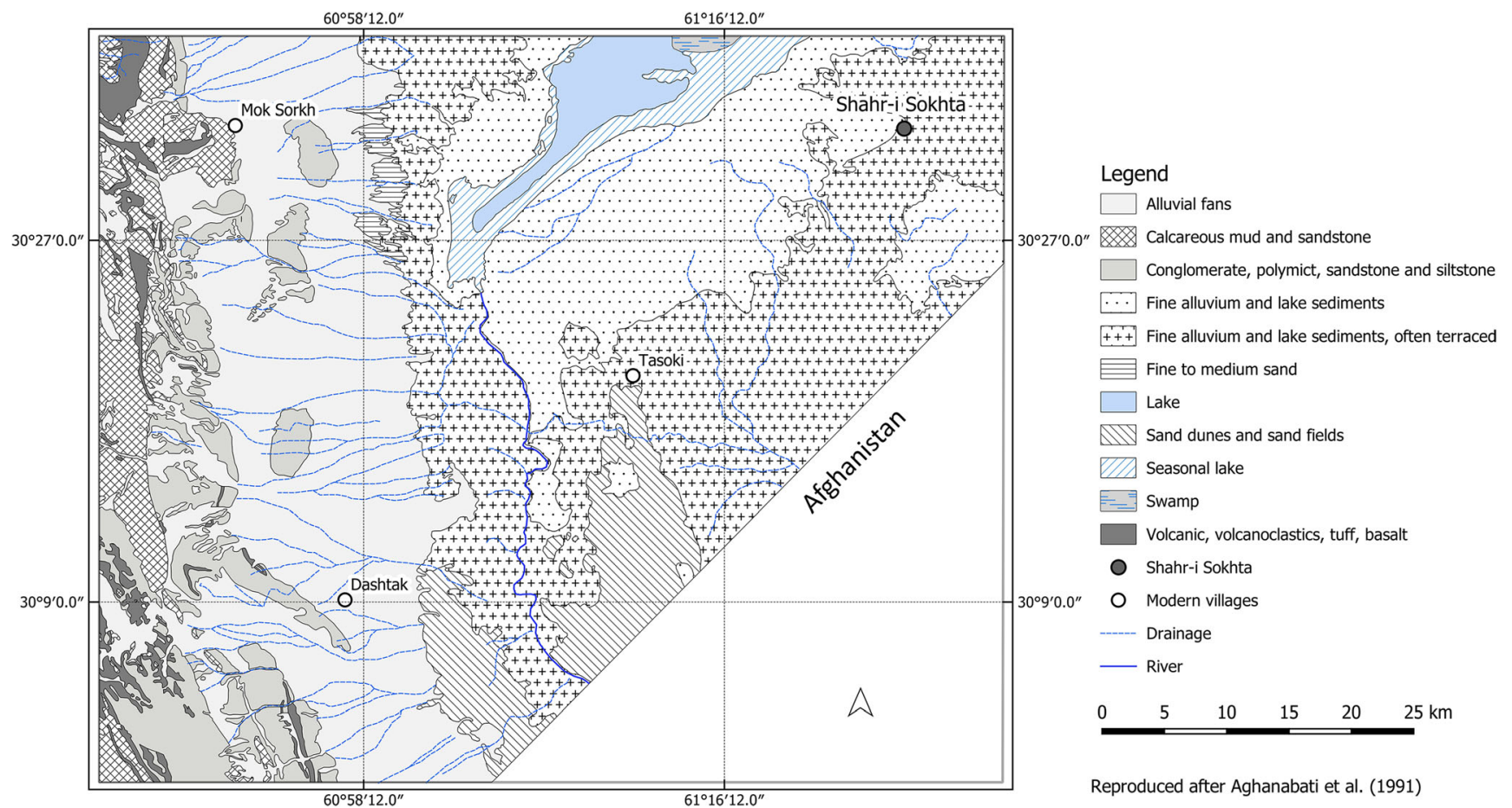

Fig. 2 Simplified geologic map of the area where Shahr-i Sokhta is located (after Aghanabati et al. 1991) 
Fig. 3 Potshards, vitrified kiln wasters, and local clay samples

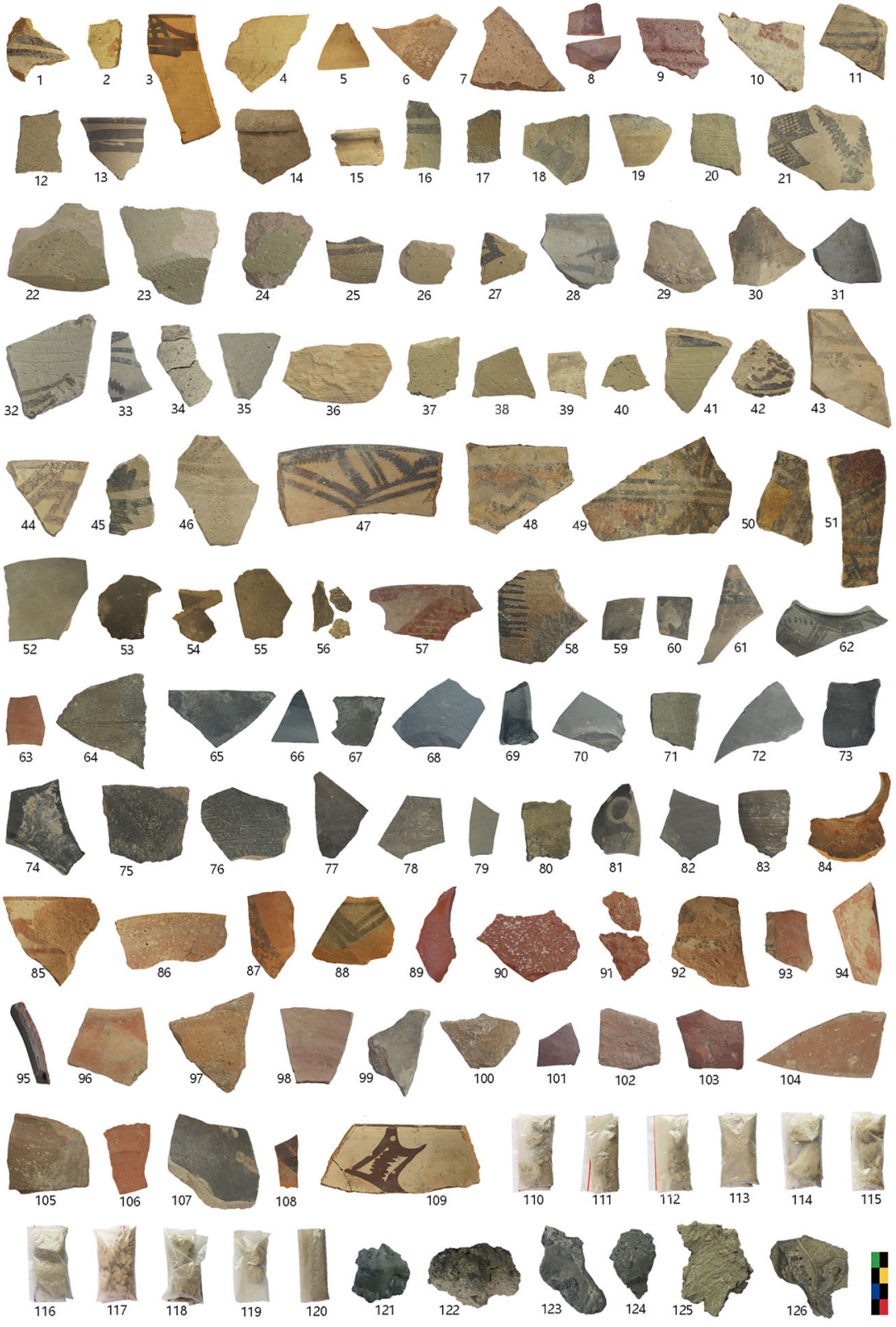

samples and the red ware shards included 6 decorated and 20 undecorated ceramics. While the buff ware bodies were fine- to coarse-grained, most of the gray and red wares exhibited a compact, homogenous, and fine-grained texture. Images of the samples are included in Fig. 3 and further information about each of the samples and their original location in the site can be found in Table 1 and Table 1.S1 in Supplementary Material 1. In addition to the pottery shards, 6 vitrified ceramics (i.e., wasters from ancient kilns) from different parts of the site and 11 raw clay samples selected from the site and clay deposits near Shahr-i Sokhta were also collected. Additional information regarding the location of the local clay samples and the vitrified wasters has been provided in Figure 1.S1 and Figure 2.S1 in Supplementary Material 1.

\section{Polarized light microscopy}

Eight thin sections of shards representing each of the 3 types of ceramics under study (buff, red, and gray wares) were prepared for petrographic analysis. Pore size, general features of the texture, and the incorporation of fine or coarse minerals were determined by polarized light microscopy following the protocol of Whitbread (2007) that was revised by Quinn (2013) to characterize the fabrics that comprised the ceramic paste and the minerals and rocks within aplastic inclusions. Petrographic observations were performed using an OPTIKA B-600POL-I polarized microscope. The microscope was equipped with a MOTICAM $25005.0 \mathrm{M}$ pixel webcam operated by Motic Images Plus 2.0 ML software. 
Table 1 The samples subjected to analysis

\begin{tabular}{|c|c|c|c|c|c|c|c|c|c|}
\hline \multirow[t]{3}{*}{ Sampling area } & \multirow[t]{3}{*}{ Local clay } & \multirow[t]{3}{*}{ Vitrified waster } & \multicolumn{7}{|c|}{ Ceramics* } \\
\hline & & & \multicolumn{3}{|c|}{ Buff } & \multicolumn{2}{|c|}{ Grey } & \multicolumn{2}{|c|}{ Red } \\
\hline & & & M & $\mathrm{U}$ & $\mathrm{P}$ & M & $\mathrm{U}$ & M & $\mathrm{U}$ \\
\hline Museum collections & - & - & 5 & 5 & 4 & 2 & 5 & 6 & 5 \\
\hline East of the Burnt building & - & - & 3 & 4 & - & - & - & - & 2 \\
\hline The trench near the Burnt building & - & - & 1 & 2 & - & - & 2 & - & 2 \\
\hline Oriental Residential Area & - & 1 & 3 & 4 & - & 3 & 5 & - & 1 \\
\hline Between Burnt building and Monumental Area & - & 2 & - & - & - & 1 & 5 & - & 1 \\
\hline The Monumental Area & 2 & - & 3 & 7 & - & 1 & 2 & - & 4 \\
\hline Central Residential Area & - & 1 & 3 & - & - & 1 & 2 & - & 3 \\
\hline Industrial zone & 1 & 2 & 3 & 2 & - & - & 3 & - & 2 \\
\hline Graveyard & 1 & - & - & - & 2 & - & - & - & - \\
\hline Burnt building & 2 & - & & & & - & & & \\
\hline Brick factory near site & 5 & - & & & & - & & & \\
\hline Total & 11 & 6 & & & & 109 & & & \\
\hline
\end{tabular}

* $M$ monochrome, $P$ polychrome, $U$ undecorated

\section{WDXRF}

The samples were cut, pulverized, pressed into powder pellets, and analyzed by an ARL Advant-XP spectrometer following the full matrix correction method suggested by Lachance and Traill (1966). Loss on ignition (LOI), which is a measure of the content of carbon dioxide and any other volatile components, including organic materials, was determined by weighing the samples before and after heating at $1000^{\circ} \mathrm{C}$. The relative error of these measurements was less than $2 \%$ for major and minor elements and less than 5\% for trace elements; the detection limits for trace elements ranged from 1 to $2 \mathrm{ppm}$. We used the certified reference materials that were specifically suggested and certified for ceramics analysis by Istituto di Scienza e Tecnologia dei Materiali CeramiciConsiglio Nazionale dell Ricerche (ISTEC-CNR). The compositional data of the 126 studied samples (including potshards, local clays, and vitrified wasters) are presented in Table 1.S2 in Supplementary Material 2.

\section{SEM-EDS}

A ZEISS EVO MA 15 scanning electron microscope (SEM) coupled with an energy-dispersive X-ray spectroscopy (EDS) system (Aztec Oxford) and equipped with a silicon drift detector (SDD), a LaB6 filament as an electron source, and cobalt as a calibration standard were used for microstructural characterization and to determine the chemical compositions of samples from thin sections and local clays. Thin sections of shards representing each type of pottery (i.e., gray, red, and buff wares) were studied at $20 \mathrm{kV}$ and an $8.5 \mathrm{~mm}$ working distance under a high vacuum.

\section{Results}

\section{Petrographic analysis}

The petrographic analyses revealed that the structural and compositional features of the bodies of gray and red wares are very different from those of the buff ware, as the latter contained a low percentage of clayey matrix and relicts of carbonate grains. The coloration of pastes used to make buff ware varied from very light beige to yellow to deep beige; by contrast, the color of the red ware paste was carmine red, and the color of the gray ware varied from gray to anthrax gray under polarized light. Only the red and gray wares exhibited a regular sintered matrix. The matrix of the buff ware samples exhibited a high percentage of tiny carbonate sub-grains (i.e., a micritic texture) with only partial formation of glassy phase that most likely resulted from the decomposition of calcite. Large relicts of calcite and quartzite were detected in the buff ware petrofabrics. Quartz was the main component of the non-clay raw materials; quartz is typically detected by its weak birefringence and undulatory extinction under polarized light (Fig. 4).

The matrix structure of the buff ware varied from hypocrystalline to a micro-granular containing fine sand and silt. In addition, in the buff ware, fine sand-sized grains consist of predominant quartz together with lower amounts of quartzite, felsic volcanic rock fragments, altered volcanic glass, 
feldspar, and biotite. Coarse sand-sized grains are comparatively less abundant and include trachytes, aphiric basalts, and carbonate rock fragments (limestone) (Fig. 5). Also, microscopic observations suggest that our samples of buff ware were generated from calcium $(\mathrm{Ca})$-rich clay, thereby revealing the calcareous nature of the original clay used for manufacturing these wares. SEM images and EDS micro-analysis of the cross-sections of the buff ware bodies revealed occasional scattered round-shaped pyroxene, plagioclase, and olivine crystals embedded in the matrix of vesicular volcanic glass (Fig. 6). The carbonates were present in fine grains. Large relicts of calcite were detected only rarely; the coarse grains of silicate rocks consisted of magmatic fragments, presumably of trachyte and andesite lithologies (Fig. 5).

The macro voids in the red ware bodies were mostly linear, ranging in size from 0.05 to $2 \mathrm{~mm}$ with parallel stretches to the walls and partially filled with secondary calcite. Overall, two types of red body-paste ceramics were identified in the sample collection obtained from Shahr-i Sokhta. The first type of ceramic was characterized by a massive vitrophyric matrix that had very low porosity and only rare mineral inclusions. The bodies of these ceramics were also characterized by an abundance of very fine quartz silt within a highly sintered clay matrix that was obtained from purified clay. The very low porosity of the bodies of red ware ceramics with a homogenous color relates directly to the high degree of sintering and the dispersion of iron oxide in a matrix containing very fine quartz microliths (Fig. 7a). The second type of red ware ceramics included those with a vesiculate vitrophyric matrix with a fine vegetal-tempered fabric. There were very few inorganic inclusions in the matrix of this second type of red ware; those detected were composed primarily of monocrystalline quartz, with smaller amounts of fine grain quartzite, felsic volcanic rocks with altered volcanic glass together with feldspar, quartz, and biotite (Fig. $7 \mathrm{~b}-\mathrm{d}$ ).

The thin section of gray ware evaluated under the microscope revealed an aphyric structure with an absence of tempers. Gray/black ware potshards were hypocrystalline with micro grains of carbonate and glass that were components of the raw clay starting materials. Two types of bodies were identified in ceramics generated with gray pastes: (a) bodies comprised of silicate glass that were characterized by a non-colored glass border with iron minerals and/or an Fe-rich vitrified matrix with microlites of carbonate (Fig. 8a) and (b) those with Fe-rich glass and minerals (i.e., magnetite and sulfides; Fig. 8b-d).

\section{WDXRF data}

The quantitative data shown in the box-and-whisker plots (Fig. 9) reveal high variances among the gray and red wares for most of the major elements. By contrast, the buff wares and the local vitrified clay samples exhibit relatively low variances, suggesting that these groups have unique compositions. It should be highlighted that the weightpercent range of $\mathrm{CaO}$ determined for both the buff ware and for the local vitrified wasters falls within the known composition of calcareous clay bodies (i.e., $>6 \%$ of the weight from $\mathrm{CaO}$ ). By contrast, the $\mathrm{CaO}$ content determined for both the red and gray wares covers a larger range of potential chemistries, including those associated with both calcareous and noncalcareous bodies. Similarly, the low variance associated with $\mathrm{SiO}_{2}$ and $\mathrm{Al}_{2} \mathrm{O}_{3}$, as well as the higher and lower mean values of $\mathrm{SiO}_{2}$ and $\mathrm{Al}_{2} \mathrm{O}_{3}$ content, respectively, exhibited by both the buff ware and vitrified wasters reveal that these ceramics are rich in quartz and contain comparatively less clay. Furthermore, the lower mean content of $\mathrm{Fe}_{2} \mathrm{O}_{3}$ accompanied by the high $\mathrm{CaO}$ content in both the buff ware and vitrified clays explains the characteristic buff color of these ceramics (Fig. 9).

The box-and-whisker plots also demonstrate strong similarities between elements comprising the local vitrified wasters and the buff ware ceramics and likewise document the significant differences between the properties of these ceramics and those of the red and gray wares. As such, one might conclude that the compositional range of the gray and red wares is entirely different from those exhibited by buff ware ceramics and also from the properties of the local clays. These results also suggest that the studied gray and red wares might indeed include multiple compositional groups, due to the high variances with respect to their composition. By contrast, the low compositional variance exhibited by the buff ware samples is consistent with the theory that these ceramics originate from sources similar to those of the local vitrified kiln wasters (Fig. 9).

As suggested by the bivariate plots in Fig. 10, buff ware ceramics, local clay, and vitrified wasters can be grouped with several of the samples with gray- and red-paste bodies (Group I); another group of red and gray wares formed a separate cluster (Group II). Of significant interest, thin section petrography of the red and gray wares also distinguished between these two specific groups (see "Petrographic analysis"). Several bivariate plots of rubidium $(\mathrm{Rb})$, strontium $(\mathrm{Sr})$, potassium $(\mathrm{K})$, and Ca pairs revealed further details regarding chemical variation within the ceramic bodies. Earlier studies have documented $\mathrm{Rb}$ incorporation in K-based minerals as well as $\mathrm{Sr}$ in $\mathrm{Ca}$ based minerals (Plimer and Elliott 1979); as such, the relationships between these elements may reveal meaningful connections to the composition of the primary rocks that comprise the various ceramic bodies. As shown in Fig. 10, we were able to distinguish between two groups of ceramics based on the chemical compositions of collected pottery shards. However, we note that the Sr content of several of the samples of local clay is lower than that identified in some of the local ceramic products (Fig. 10) (see Discussion). 
Fig. 4 Low magnification $(5 \times)$ plane-polarized light microscope images of (a) the buff-colored body of polychrome shard no. 10 , (b) the buff-colored body of polychrome shard no. 48 , (c) the buff-colored body of polychrome shard no. 49, (d) the gray-colored body of shard no. 52, (e) the graycolored body of shard no. 62, (f) the gray-colored body of shard no. $83,(\mathrm{~g})$ the red-colored body of shard no. 104 , and (h) the redcolored body of shard no. 93
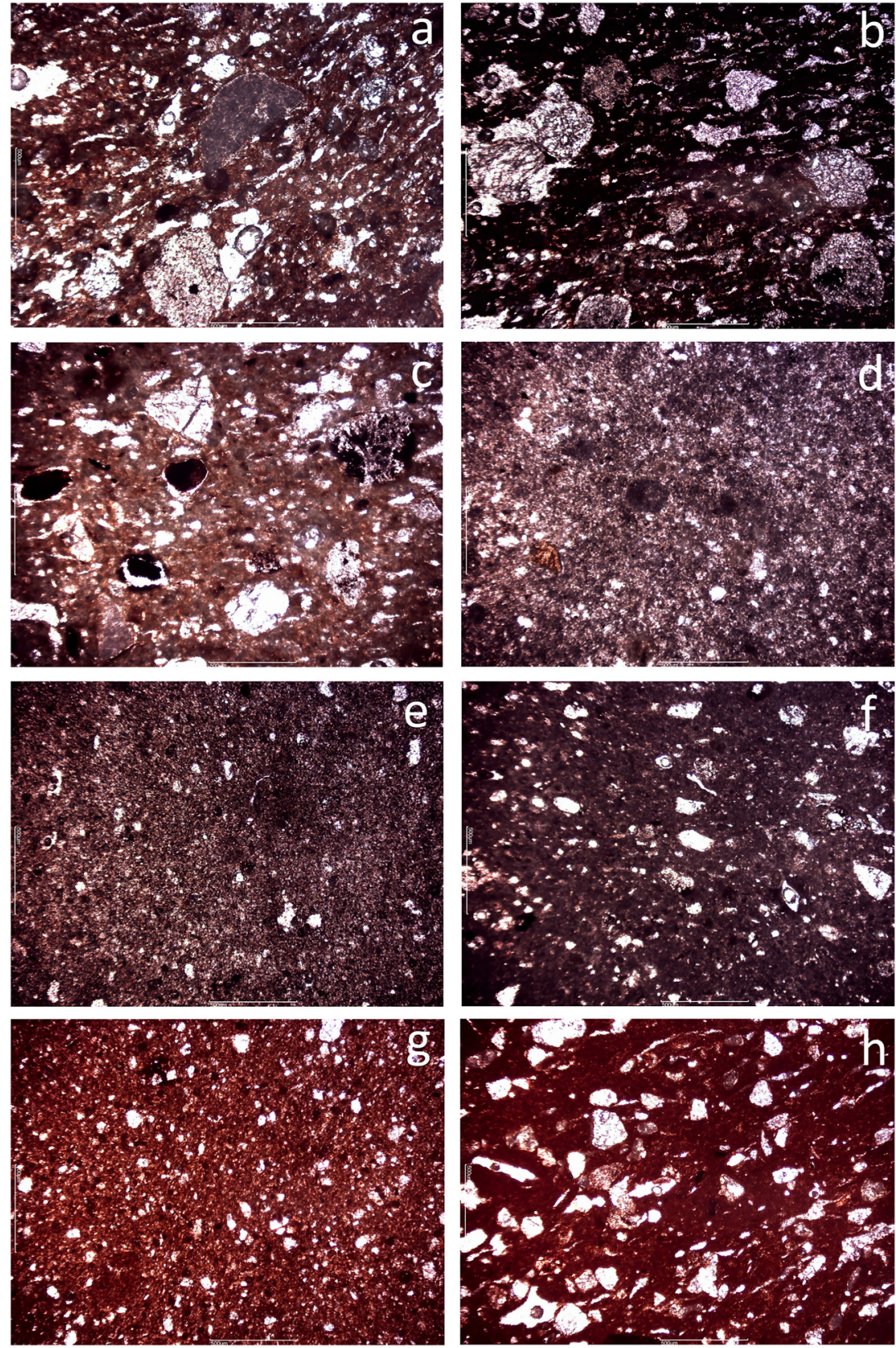

\section{Discussion}

\section{The question of provenance}

As mentioned earlier, high $\mathrm{Ca}$ and $\mathrm{Sr}$ levels were found within the bodies of the ceramics in Group I; volcanic and tuffaceous inclusions in the bodies of these ceramics suggest that they are most likely to have been produced locally (see "Geological setting"). By contrast, the high levels of silicon ( $\mathrm{Si}$ ), zirconium $(\mathrm{Zr}$ ), and $\mathrm{Rb}$ (see Table 1 in Supplementary Material 2) detected in the samples of red and gray ware clustered in Group II may indicate that the clay used to generate these ceramics was derived from felsic (acidic) rocks (Blackman et al. 1989) although the occurrence of these elements in a certain clay can also be connected to many other sources. We note that raw materials with these chemical constituents have not been identified in this region (Aghanabati et al. 1991) (see also "Geological setting"). As such, these ceramics were probably manufactured from the clays derived from Si-rich granite with mineralization yielding a high $\mathrm{Rb} / \mathrm{Sr}$ ratio as a result of fractionation (Plimer and Elliott 1979).

The low Sr content of several of the samples of local clay may be explained by the fact that the Sr content of ancient pottery may be altered by firing and burial (Poole and Finch 
Fig. 5 (a) Carbonatic grain in the hypocrystalline matrix of a buffcolored body (sample no. 10), (b) dark vitrophytic glassy matrix characterized by sialic acicular spinifex crystals (olivine; sample no. 10), (c) aphyric basalt/ andesite fragment composed of microliths of pyroxene, amphibole, and plagioclase with interstitial oxide and biotite phases, (d) a terrigenous component characterized by the fine alluvium and lake sediments characteristic of those found in the outcrop around the Shahr-i Sokhta archaeological areas (sample no. 10), (e) trachyte fragments with porphyritic textures and sanidine phenocrysts, interstitial microliths of biotite and rare plagioclase, magnetite and quartz crystals (sample no. 49), (f) chlorite as secondary phase (sample no. 48), (g) initial phase of quartz reacting with other components of the paste and high degree of sintering in the buff-colored body of sample no. 48 ; (h) initiation of a reaction between quartz and matrix of a buffcolored body due to high firing temperatures (sample no. 48)
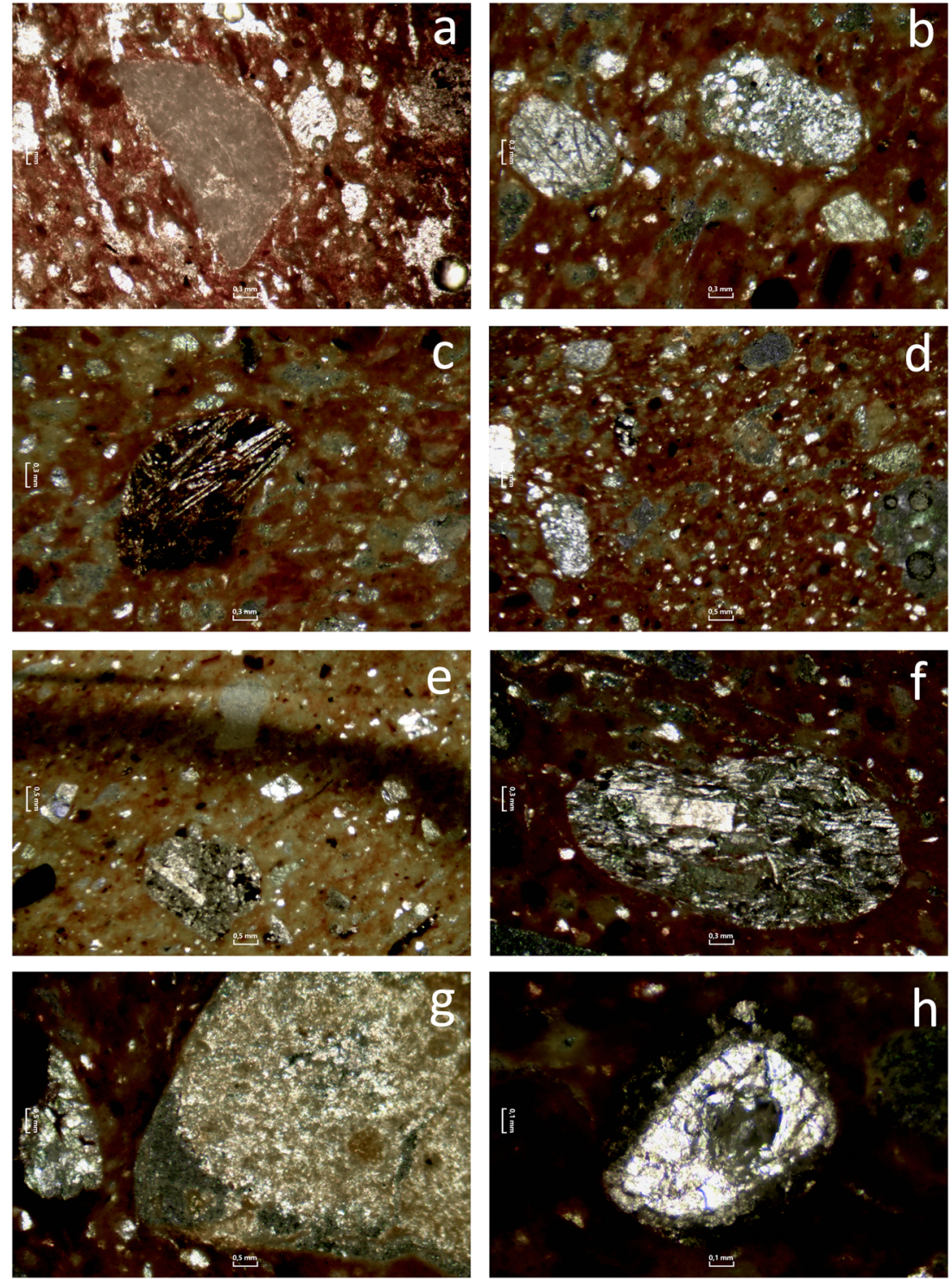

1972), although the concentrations of the other important elements used in provenance studies of ancient pottery are not affected by firing (Kilikoglou et al. 1988; Cogswell et al. 1996). Accordingly, the chemistry of the local vitrified wasters, which has been considered to be the most appropriate source material for estimates of the chemical composition of locally produced ceramic products, was in good agreement with the chemistry of the ceramics clustered in Group I.

The results of chemical and petrofabric analyses of the polychrome ware presented in this study suggest significant similarities with local buff ware. These findings suggest that these polychrome ceramics were also made locally and were not imported. Studies of the indigenous geology at the Shahr-i Sokhta location were also consistent with findings from the WDXRF and petrographic analyses. The magmatic particles identified in the bodies of the ceramics in Group I may have originated from the calcalkaline magmatic rock outcropping found in the mountain ranges adjacent to the city of Zabol, which resulted from the subduction of oceanic lithosphere before the Neotethyan closure of the continental margins (Martin and Piwinskii 1972). These volcanic rocks are mainly porphyritic in texture and consist of trachyte, trachyandesite, andesite, latite, latite-andesite, and dacite.

Additional evidence for the local production of buff and polychrome ware was obtained from the results of EDS microanalysis of the local clay samples. As shown in Fig. 11, local clays featured pyroxene and feldspar inclusions, consistent with basaltic and tuffaceous clasts originating from rocks in this region. As such, it is not surprising to find scattered basaltic and tuffaceous clasts and mafic chemistry within clay deposits from this area. 

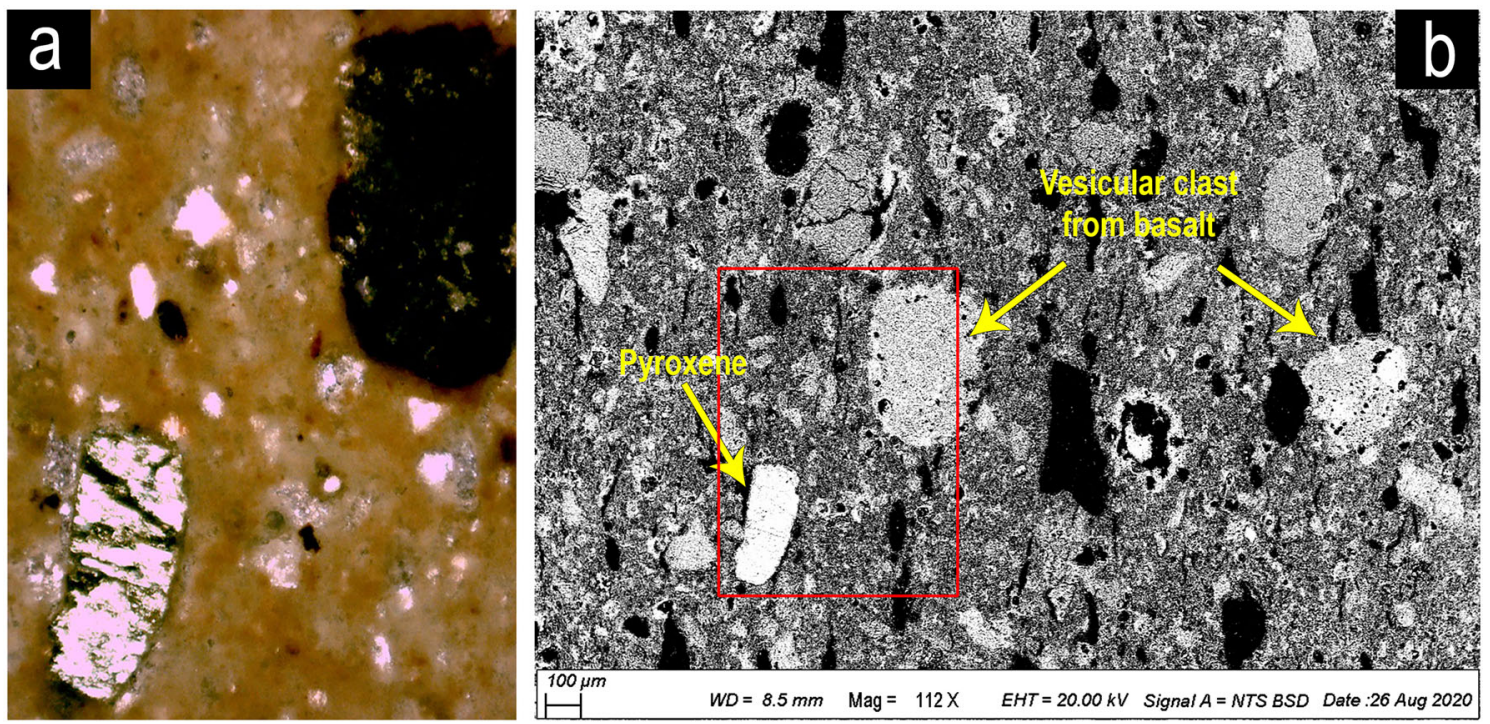

Fig. 6 (a) Plane polarized light microscope image from a cross-section of polychrome sample no. 49 together with (b) an SEM micrograph from a crosssection obtained from the same sample; the area observed in Figure 4a is highlighted within a red rectangle

The findings from WDXRF and petrofabric analysis suggest that a group of ceramics with red and gray bodies (Group II) were imported to Shahr-i Sokhta. Unlike the ceramics with buff bodies, most of these ceramics were decorated with paintings of fine and delicate animal figures, as well as vegetal and geometric patterns (Lamberg-Karlovsky et al. 2001; Sajjadi 2005). The walls of the ceramics in this group were somewhat thinner than those of the local buff-colored pottery samples (Lamberg-Karlovsky et al. 2001; Sajjadi 2005). These ceramics were found in the layers representing different periods of settlement at this site, suggesting large-scale and long- standing connections between Shahr-i Sokhta and the other civilizations in this region.

The results of this study also identify a group of red and gray wares unearthed from Shahr-i Sokhta that clustered together with the local buff ware ceramics based on similar levels of $\mathrm{SiO}_{2}, \mathrm{TiO}_{2}, \mathrm{CaO}$, and $\mathrm{Fe}_{2} \mathrm{O}_{3}$. The chemical composition of these ceramics might have been altered by high temperatures and uncontrolled firing in a kiln. The existence of these ceramics at this site suggests that high-temperature furnaces may have been in use at Shahr-i Sokhta. It is interesting to note that furnaces from a time period that was parallel to
Fig. 7 (a) Homogeneous distribution of red clay without aggregates together with midgray/black features in cores of sample no. 104, (b) darkened mid-gray/black cores in the red ware pottery in sample no. 93, (c) the red argillaceous matrix that is equidimensional to the segment of elongated mudstone in the second group of the ceramics with red-colored bodies (sample no. 93), (d) an SEM micrograph from the red paste of sample no. 88 which exhibits a uniform and homogenous iron-rich sintered fabric with angular to round pores
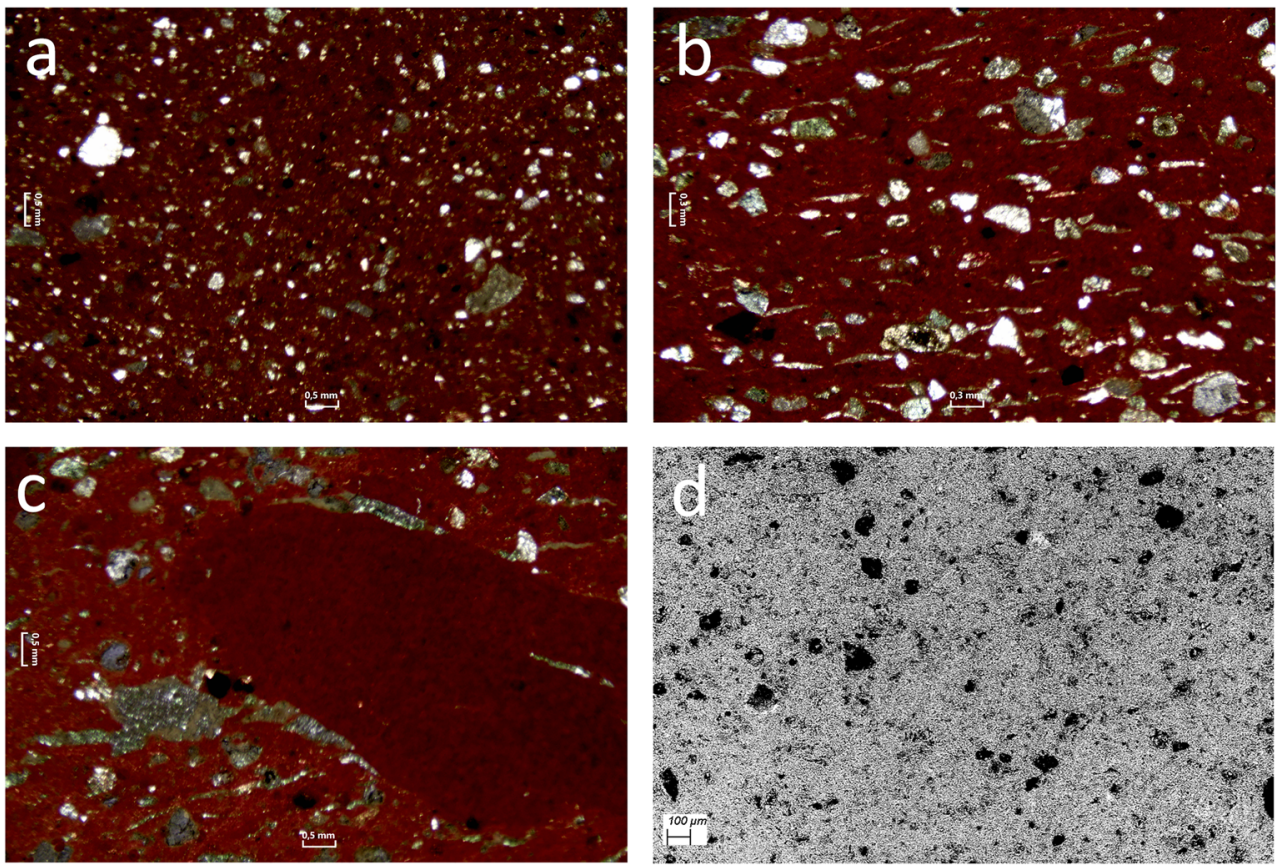
Fig. 8 (a) The amorphous matrix with very fine quartz, calcareous grain, and rounded microvoids distributed without preferential orientation in the first group of the gray ware ceramics (sample no. 62 ), (b) the matrix of the second group of gray wares that was rich in mineralized organic substance (sample no. 83), (c) an iron-rich (magnetite) rim with a core of transparent glass in the graycolored body of sample no. 52, (d) an SEM micrograph of the thin section of gray ware (sample no. 62) shows a fine and homogenous sintered matrix
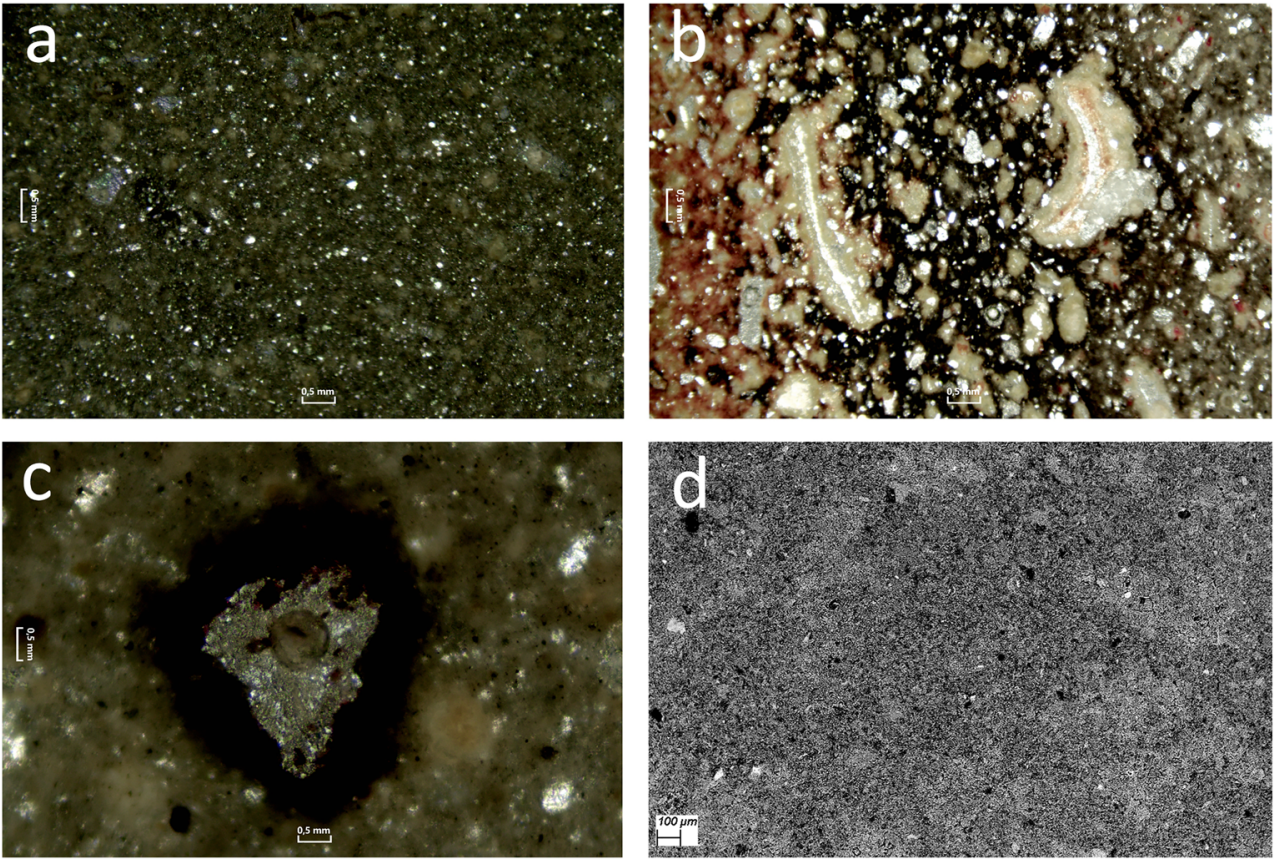

Period III of Shahr-i Sokhta have been identified at Tepe Rude Biyaban, where ceramics that are similar to those unearthed at Shahr-i Sokhta have been found (Tosi 1969; Vidale and
Bennici 1995; Forte et al. 1998). Further studies will be needed to explore the connections between pottery production in Tepe Rud-e Biyaban and Shahr-i Sokhta.
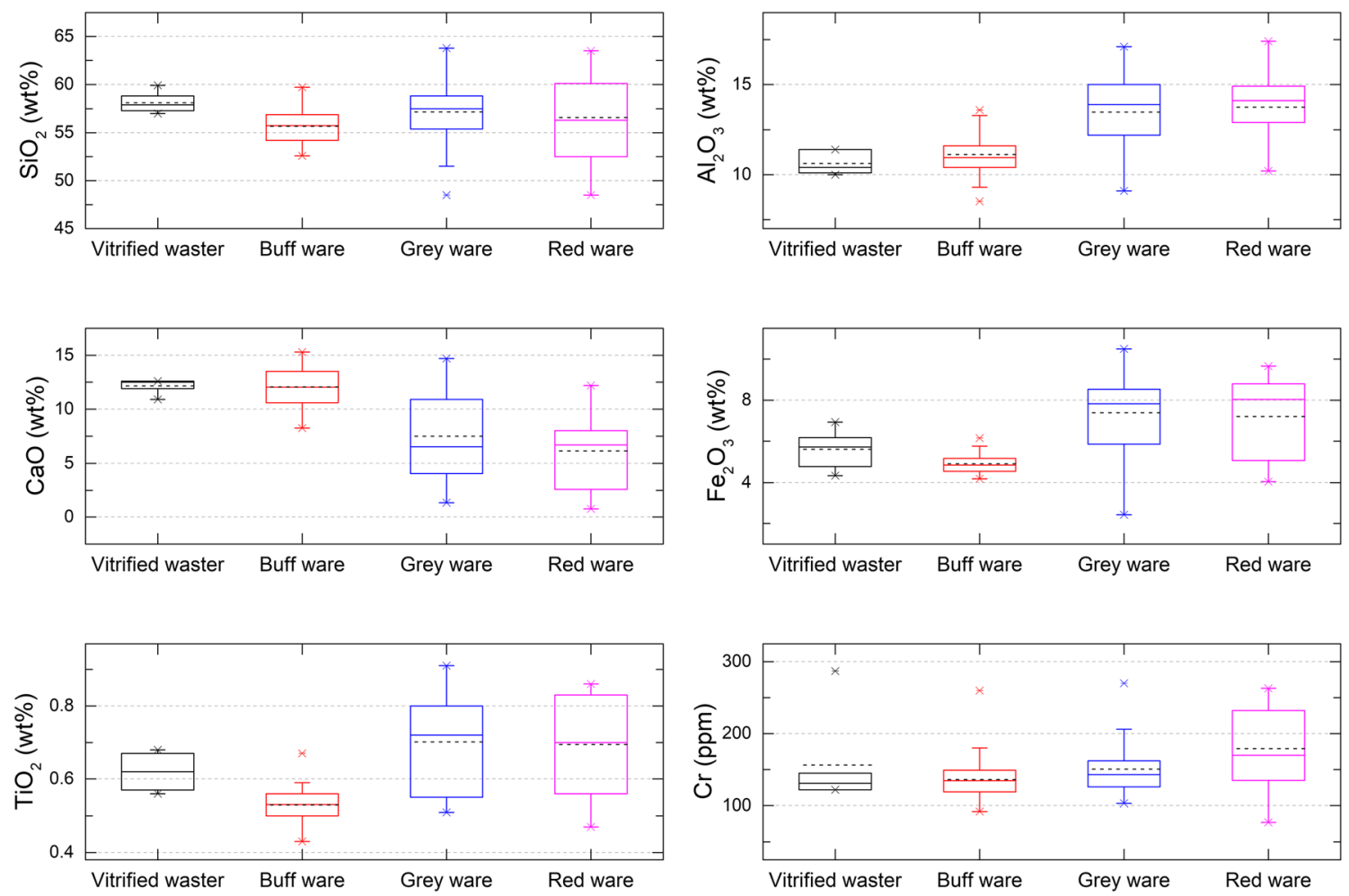

Fig. 9 Box-and-whisker plot of the quantitative data documenting the properties of the gray, red, and buff wares; the minimum/maximum, mean, and median values are shown with asterisks, a black dashed line,

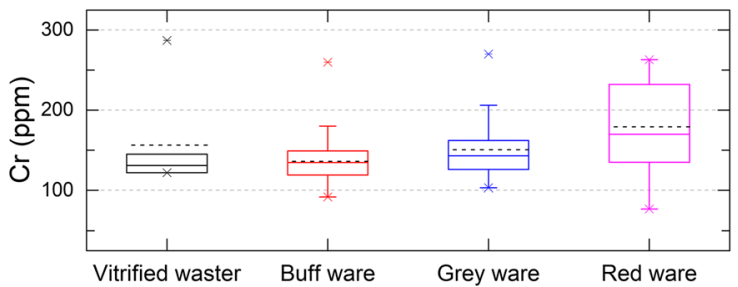

and a black solid line, respectively. Outliers are outside the range are also marked with asterisks 


\section{A note on technological aspects of the ceramics}

The connected large pores and high elongation of voids found in the clayey matrix of the buff and red ware samples may contribute to its increased permeability and, at the same time, its decreased capacity to resist transverse rupture. The pores serve to improve its toughness and resistance to thermal shock, thereby preventing the propagation of cracks generated by the differential expansion of interior and exterior vessel walls upon heating or cooling (Eramo 2020). On the other hand, the bodies of both gray and red ware included a highly sintered matrix rich in iron oxide $\left(\mathrm{Fe}_{2} \mathrm{O}_{3}\right)$. The iron oxide may result from the destruction of iron $(\mathrm{Fe})$-containing minerals and their recrystallization to form secondary crystals during the firing process. Hematite formed in the oxidizing atmosphere of a kiln provides the characteristic reddish color of

- Local clay $\bigcirc$ Vitrified waster $\bigcirc$ Buff ware 0 Red ware

Grey ware $\bigcirc$ Monochrome $\bigcirc$ Polychrome - Undecorated
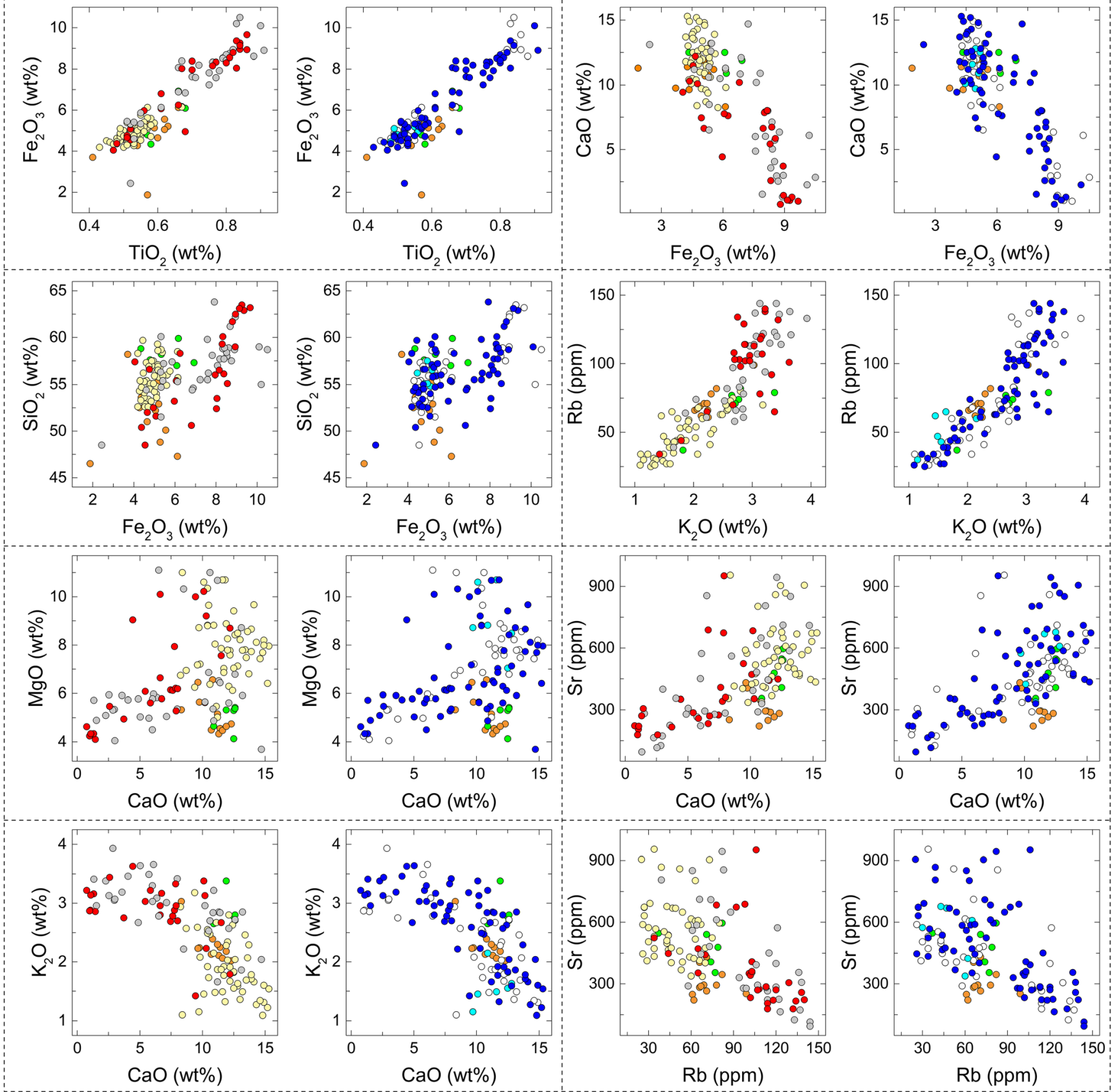

Fig. 10 Bivariate plots of major, minor, and trace elements identified in the pottery shards under study. In each pair, the graphs on the left are plotted based on the color of the body paste (i.e., red, gray, or buff);

graphs on the right present the same data grouped by type (i.e., undecorated, monochrome, or polychrome) 
Fig. 11 Backscattered electron SEM images of local clay reveal (left) components including quartz, feldspar, and pyroxene within the matrix; (right) detailed image of a basaltic clast identified in the sample (no. 110) of local clay
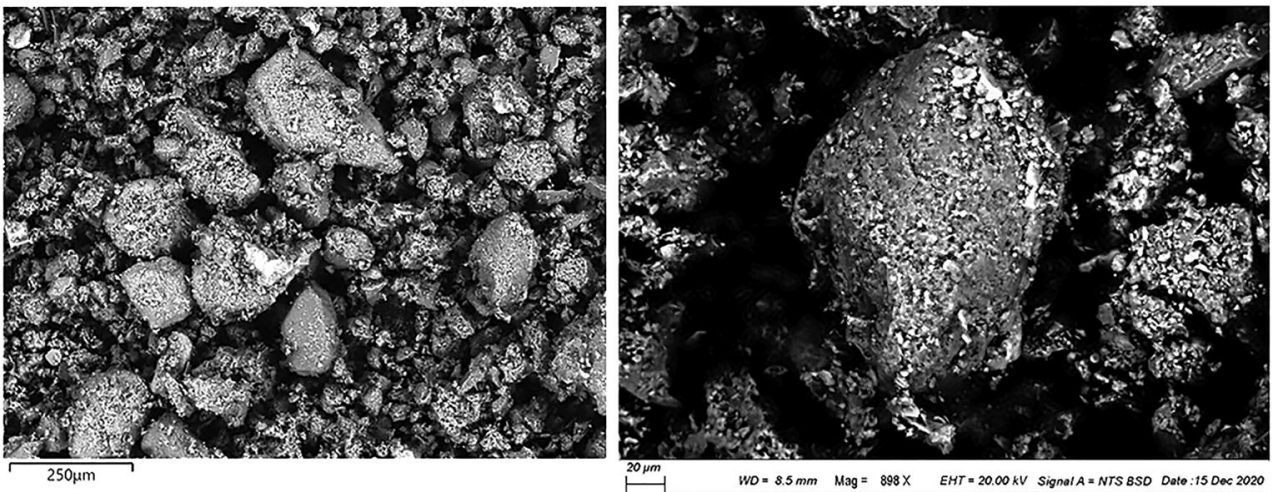

this form of pottery. Of note, the presence of calcareous lumps in Ca-rich clay can prevent the formation of hematite crystals via fixation of $\mathrm{Fe}$ in the network of newly formed calcareous silicate and aluminosilicate minerals; this interaction could ultimately inhibit the generation of red color in the fired pottery (Rice 1996). As such, the Ca content of red wares is frequently low.

\section{Conclusion}

In this study, we questioned an old assumption regarding the provenance of polychrome ware from Shahr-i Sokhta and provided new results suggesting that these ceramics were most likely local, not imported products. This hypothesis re-opens this discussion and may ultimately raise new questions to be addressed by future archaeological studies of the region. In accordance with the results from archaeological and stylistic studies, our findings also suggest that ceramics with buffcolored bodies from Shahr-i Sokhta are most likely made from local calcareous clay deposits. However, there is less clarity with respect to the red and gray wares that were unearthed at this site. While a large group of these wares could be distinguished by their chemistries and petrofabric analysis, several of the gray and red ware pottery shards displayed properties that were strikingly similar to those of local products. Further research will be needed to determine the provenance of this unique group of red and gray ware ceramics found at Shahr-i Sokhta. Future research might also focus on the ceramic products found at Tepe Rud-e Biyaban in order to explore its potential influence on pottery production in Shahri-i Sokhta.

Supplementary Information The online version contains supplementary material available at https://doi.org/10.1007/s12520-021-01307-2.

Acknowledgements The authors are grateful to Hamed Sayyadshari for his valuable help and Renzo Tassinari for performing WDXRF analyses. We also wish to thank the offices of Cultural Heritage, Handicrafts, and Tourism Organization of Iran in Sistan and Baluchistan Province and the Research Base Centre of Shahr-i Sokhta for providing the samples.
Funding Open access funding provided by Università degli Studi di Ferrara within the CRUI-CARE Agreement.

Open Access This article is licensed under a Creative Commons Attribution 4.0 International License, which permits use, sharing, adaptation, distribution and reproduction in any medium or format, as long as you give appropriate credit to the original author(s) and the source, provide a link to the Creative Commons licence, and indicate if changes were made. The images or other third party material in this article are included in the article's Creative Commons licence, unless indicated otherwise in a credit line to the material. If material is not included in the article's Creative Commons licence and your intended use is not permitted by statutory regulation or exceeds the permitted use, you will need to obtain permission directly from the copyright holder. To view a copy of this licence, visit http://creativecommons.org/licenses/by/4.0/.

\section{References}

Aghanabati A, Eftekharnejad J, Alavi Naini M (1991) Geological map of the Daryache-ye Hamoon, 1:250000. Geological Survey and Mineral Exploration of Iran, Tehran

Biscione R (1974) Relative chronology and pottery connections between Shahr-i Sokhta and Mundigak, Eastern Iran.” Memorie del'Istituto Italiano di Paleontologia Umana, 2: 131-145

Biscione R, Salvatori S, Tosi M (1977) Shahr-i Sokhta: l'abitato protostorico e la sequenza cronologica. Tucci, ed, 77-113

Biscione R (1979) Centre and periphery in Late Protohistoric Turan: the settlement pattern. Reimer

Biscione R (2010) Iran. Campagne 2007-2008 a Shahr-Sokhta (Sistan, Iran Orientale) e nuove ricerche sulla crisi dell'urbanizzazione della fine del III millennio aC. Studi micenei ed egeo-anatolici 52(1):289-296

Blackman MJ, Mery S, Wright RP (1989) Production and exchange of ceramics on the Oman Peninsula from the perspective of Hili. J Field Archaeol 16(1):61-77. https://doi.org/10.1179/jfa.1989.16.1.61

Cogswell J, Neff H, Glascock M (1996) The effect of firing temperature on the elemental characterization of pottery. J Archaeol Sci 23:283287. https://doi.org/10.1006/jasc.1996.0026

Cortesi E, Tosi M, Lazzari A, Vidale M (2008) Cultural relationships beyond the Iranian plateau: the Helmand Civilization, Baluchistan and the Indus Valley in the 3rd millennium BCE. Paléorient 34:5-35

Doebrich JL, Wahl RR, with contributions by Ludington SD, Chirico PG, Wandrey CJ, Bohannon RG, Orris GJ, Bliss JD, Wasy A, Younusi MO (2006) Geologic and minerals resources map of Afghanistan. Geological Survey (US) https://doi.org/10.3133/ofr20061038

Eftekhari N, Holakooei P, Sayyadshahri H, Vaccaro C (2018) Four shades of black: non-invasive scientific studies on the painted potteries from Shahr-i Sokhta, eastern Iran. J Archaeol Sci Rep 22:100 107. https://doi.org/10.1016/j.jasrep.2018.09.012 
Eramo G (2020) Ceramic technology: how to recognize clay processing. Archaeol Anthropol Sci 12(8):1-24. https://doi.org/10.1007/ s12520-020-01132-z

Festuccia S (2011) La ricerca archeologica nel Vicino Oriente: Siria, Anatolia e Iran. Con prefazione di Paolo Matthiae. Gangemi Editore spa

Forte M, Mozzi P, Zocchi M (1998) Immagini satellitari e modelli virtuali: interpretazioni geoarcheologiche della regione del Sistan meridionale. Archeologia e Calcolatori 9:271-290

Javanshah Z (2018) Chemical and mineralogical analysis for provenancing of the Bronze Age pottery from Shahr-i-Sokhta, south eastern Iran. Sci Cult 4(1):83-92

Kilikoglou V, Maniatis Y, Grimanis AP (1988) The effect of purification and firing of clays on trace element provenance studies. Archaeometry 30: 37-46. https://doi.org/10.1111/j.1475-4754.1988.tb00433.x

Lachance GR, Traill RJ (1966) A practical solution to the matrix problem in X-ray analysis. Can J Spectrosc 11:43-48

Lamberg-Karlovsky CC, Potts DT, Pittmann H, Kohl P L (2001) Excavation at Tepe Yahya, Iran: 1967-1975. The Third Millenium. Cambridge: Peabody Museum of Archaeology and Ethnology, Harvard University

Martin RF, Piwinskii AJ (1972) Magmatism and tectonic settings. $J$ Geophys Res 77(26):4966-4975. https://doi.org/10.1029/ JB077i026p04966

Moradi H, Sarhaddi-Dadian H, Bin Ramli Z, Rahman N (2013) Compositional analysis of the pottery shards of Shahr-I Sokhta, South Eastern Iran. Res J Appl Sci Eng Technol 6(4):654-659

Mugavero L (2008) Polychrome ware from Shar-i Sokhta. s.1.:ICHHTO. (in Farsi)

Pang KN, Chung SL, Zarrinkoub MH, Mohammadi SS, Yang HM, Chiu CH, Lee HY, Lo CH (2012) Age, geochemical characteristics and petrogenesis of Late Cenozoic intraplate alkali basalts in the LutSistan region, eastern Iran. Chem Geol 306:40-53. https://doi.org/ 10.1016/j.chemgeo.2012.02.020

Piperno M (2006) La necropoli. In: La città bruciata del deserto salato. s.l.:Erizzio

Plimer IR, Elliott SM (1979) The use of $\mathrm{Rb} / \mathrm{Sr}$ ratios as a guide to mineralization. J Geochem Explor 12:21-34. https://doi.org/10.1016/ 0375-6742(79)90060-8

Poole AB, Finch LR (1972) The utilization of trace chemical composition to correlate British post-Mediaeval pottery with European kiln site materials. Archaeometry 14:79-91

Pourzarghan V, Sarhaddi-Dadian H, Ramli Z (2017) Morphology of ancient potteries using $\mathrm{X}$-ray diffraction analysis and $\mathrm{X}$-ray fluorescence in Sistan plain, eastern Iran. Mediter Archaeol Archaeom 17(2):175-186

Quinn PS (2013) Ceramic petrography: the interpretation of archaeological pottery and related artefacts in thin-sections. Archaeopress, Oxford

Rice PM (1996) Recent ceramic analysis: 1. Function, style, and origins. J Archaeol Res 4(2):133-163. https://doi.org/10.1007/BF02229184

Saadat S, Stern CR (2011) Petrochemistry and genesis of olivine basalts from small monogenetic parasitic cones of Bazman stratovolcano, Makran arc, southeastern Iran. Lithos 125(1-2):607-619. https://doi. org/10.1016/j.lithos.2011.03.014

Sajjadi SM (2004) The beginning of urbanization in the eastern half of the Iranian plateau (Aghaze shahr neshini dar nimeye sharghi falat Iran). Nameye Ensan Shenasi 6:63-96 (in Farsi)

Sajjadi SM (2005) The first cities on Iran plateau (Nokhostin shahrh-ye falat-e Iran). Samt, Tehran (in Farsi)

Sajjadi SM (2009) Majmoe maghalate Shahr-i Sokhta 1. s.1.:ICHTO. (in Farsi)

Salvatori S, Tosi M (2001) Shahr-i Sokhta revised sequence. South Asian Archaeology 1:281-292

Salvatori S (2006) Il panorama storico. In: La città brucita del deserto salato. s.l.:Erizzio

Sarhaddi-Dadian H, Ramli Z, Rahman A, Mehrafarin R (2015) X-ray diffraction and X-ray fluorescence analysis of pottery shards from new archaeological survey in south region of Sistan, Iran. Mediter Archaeol Archaeom 15(3):45-56

Tosi M (1969) Excavations at Shahr-i Sokhta. Preliminary Report on the Second Campaign, September-December 1968. East \& West XIX. 283-386

Tosi M (1976) A topographical and stratigraphical periplus of Shahr-i Sokhta. In: Proceedings of the 4th Symposium of Archaeological Research in Iran, 3: 130-158

Tosi M (1983) Prehistoric Sistan. IsMEO Rep. Mem. XIX, Roma, p 1

Vidale M, Bennici A (1995) Viaggio Intorno alla mia Ciotola. Instituto Universitario Orientale, Evoluzione Tecnologica e Comunicazione non Verbale in una Sequenza Ceramica dell'Eta del Bronzo

Vidale M (2010) A Oriente di Sumer: archeologia dei primi stati euroasiatici, 4000-2000 aC. Carocci

Whitbread IK (2007) The characterisation of argillaceous inclusions in ceramic thin sections. Archaeometry 28(1):79-88

Publisher's note Springer Nature remains neutral with regard to jurisdictional claims in published maps and institutional affiliations. 